Article

\title{
Organizational and Systemic Policy Capacity of Government Organizations Involved in Energy-From-Waste (EFW) Development in Thailand
}

\author{
Haruthai Chenboonthai ${ }^{1}$ and Tsunemi Watanabe ${ }^{2, *}$ \\ 1 Graduation School of Engineering, Kochi University of Technology, Kami 782-8502, Japan; \\ 208004c@gs.kochi-tech.ac.jp \\ 2 School of Economics and Management, Kochi University of Technology, Kochi 780-8515, Japan \\ * Correspondence: watanabe.tsunemi@kochi-tech.ac.jp
}

Received: 14 August 2018; Accepted: 18 September 2018; Published: 20 September 2018

\begin{abstract}
This article studies the challenges of Thai energy-from-waste (EFW) development from an institutional perspective. Policy capacity, described as conditions for effective policy development and implementation, of the main government organizations involved in EFW development under the Alternative Energy Development Plan (AEDP) 2015 is examined. Adopting the variables used under the institutional analytical and development (IAD) approach, we modified the analytical framework for policy capacity by categorizing factors contributing to policy capacity into elements (skills, resources, and process) that affect the decisions and actions of actors of government organizations. Then, the results from the in-depth interview were interpreted through a modified analytical framework to examine policy capacity at the organizational and systemic level of government organizations involved in EFW development. We believe that a modified analytical framework for policy capacity is compatible with the IAD approach and can facilitate the utilization of policy capacity for further analysis under the IAD approach. Moreover, the modified framework can encourage a better understanding of current policy capacity and its impacts on other organizations, since an organization values its own policy capacity and others' policy capacity differently. Consequently, this understanding can benefit the improvement of cooperation among Thai government organizations involved in EFW development.
\end{abstract}

Keywords: policy capacity; institutional analysis; IAD framework; organizational capacity; systemic capacity; energy-from-waste (EFW); energy policy

\section{Introduction}

The Alternative Energy Development Plan (AEDP) 2015, one of energy master plans under the Thai Integrated Energy Blueprint (TIEB), was established by the Ministry of Energy (MoEN) with the focus on energy security, economic, and ecology aspects [1]. The objective of AEDP 2015 was to develop Thai domestic alternative energy resources in order to reduce dependency on imported fossil fuels with the main target of increasing the share of renewable energy resources to $30 \%$ of final energy consumption in 2036 [2].

Targets for different alternative energy resources, for example, solar, wind, and biomass, were set in the AEDP 2015. However, energy from waste (EFW) is prioritized as the most important target because it benefits both the diversification of the national energy resources and municipal solid waste (MSW) management problems.

Concerning the EFW target achievement under AEDP 2015, effective cooperation among government organizations is extremely important. Based on the roles, responsibilities, and involvement 
in EFW development, this research considers (1) the MoEN, (2) the Ministry of Natural Resources and Environment (MoNRE), and (3) the Ministry of Interior (MoI) as the main government organizations responsible for EFW development.

To improve the effective cooperation and support among government organizations, it is important to understand the policy capacity, described as the conditions for effective policy development and implementation [3], and institutions that affect decision-making and other interactions within and across the organization [4]. Therefore, this research aims to present the challenges of EFW development in Thailand from an institutional analysis perspective because most research about Thai EFW mainly focuses on the feasibility of technologies and the impact of inefficient systems for solid waste management (SWM) [5-9].

Regarding the research aim, we examined policy capacity by adopting the elements of actors identified under the institutional analytical and development (IAD) approach to categorize factors contributing to policy capacity in the analytical framework developed by Wu et al. [10]. We created a modified analytical framework with the intention of improving the understanding of policy capacity factors and initiating the application of policy capacity as a supporting tool for institutional analysis. Finally, a modified analytical framework was used for analyzing policy capacity of the three government organizations, which is reflected in the information from the in-depth interviews.

This article starts with the background and basic information on Thai alternative energy policy, the roles and responsibilities of the main relevant government organizations, the IAD framework for institutional analysis, and the conceptualization of policy capacity. Then, the methodology and sources of information collection are described. The derived factors contributing to the policy capacity, key findings, and recommendations for policy capacity analysis are presented in the results section. Finally, the results are discussed to examine current status and impacts of policy capacity of Thai government organizations involved in EFW development.

\subsection{Context of the Alternative Energy Development Plan 2015}

Following the national energy development direction by the government, the MoEN launched the TIEB for 2015-2036 with focuses on energy security, economic, and ecology [1]. To serve TIEB, five energy master plans were developed to manage the main energy issues of the country: (1) Power Development Plan (PDP); (2) Energy Efficiency Development Plan (EEDP); (3) Alternative Energy Development Plan (AEDP); (4) Oil Development Plan; and (5) Gas Development.

The Alternative Energy Development Plan's goal was set based on the assumption that if EEDP 2015 could reach its goal of reducing energy intensity by 30\% in 2036 compared to 2010, final energy consumption demand in 2036 would be 131,000 ktoe (kilotonnes of oil equivalent) and $30 \%$ of the demand would be generated from domestic renewable energy resources in forms of electricity, heat, and bio-fuel [2]. Among different alternative energy resources, EFW is prioritized as the most important target to achieve.

To achieve the EFW target, effective cooperation and support from the relevant government organizations are extremely important, especially from waste management and energy sectors. Consequently, it is useful to understand the scopes of the roles and responsibilities of the main government organizations involved in EFW development from different positions and steps in the policy process.

\subsection{Major Government Organizations Involved in EFW Development}

As noted, this research considers the MoEN, MoNRE, and MoI as the main actors involved in EFW development under AEDP 2015. To clarify their working relationship, the scope of their roles and responsibilities is presented through functional elements in the SWM diagram in Figure 1.

The MoEN supports the EFW development through AEDP 2015 by prioritizing EFW over other resources. Moreover, different incentive measures and support, mainly in the form of funding, 
are provided to attract and elevate the level of interest in EFW development and investment, especially from private sectors.

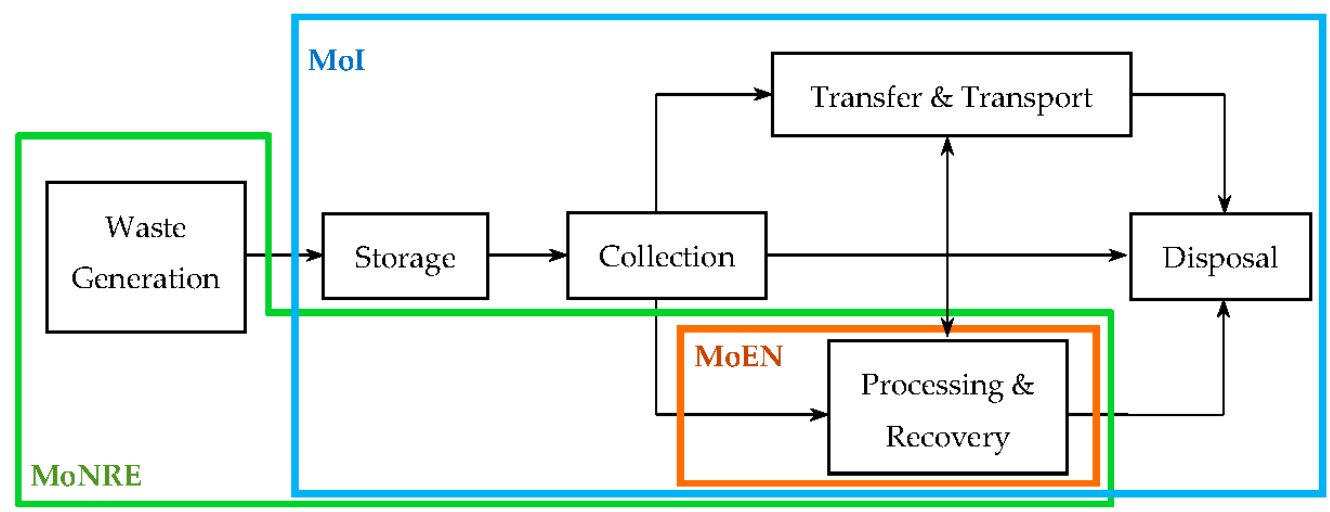

Figure 1. Scope of roles and responsibilities of different government organizations under functional elements in the solid waste management diagram.

Meanwhile, the MoNRE launched the National Solid Waste Master Plan (2016-2021) with the aim to control and reduce the national MSW generation rate [11]. Following the waste management hierarchy, the Reduce, Reuse, and Recycle (3R) campaign was promoted for the reduction of waste generation and the increase of waste separation, which directly benefit both the SWM system and EFW development.

The Ministry of Interior is responsible for controlling and managing the SWM system. With support from the MoNRE as the regulator and consultant, they set up action plans and policies to manage the SWM system, which is consistent with the National Solid Waste Master Plan. In addition to the responsibilities in managing the SWM system, the MoI also has the authority to decide how to treat or manage the collected waste, as the collected waste is considered as having properties of the MoI [12].

Effective cooperation and support among government organizations for EFW development are not only affected by their roles and responsibilities, but also the policy capacity and institutions. As a result, an understanding of the policy capacity and institutions that affect the policy work is required.

\subsection{Institutional Analytical and Development Framework for Institutional Analysis}

Institutions are described as different forms of entities, including both organizations and the rules used to structure patterns of interaction within and across organizations [13]. Institutions can be formal, such as law, policy, or procedure, and informal, such as common understanding, belief, or norm $[4,13]$. In the policy environment, institutions are abstract and invisible as they are shared concepts in the policy participants' minds and routines [4]. Institutions are important for policy process because they construct information and create incentives for actors' decisions which impact the patterns of interaction and the policy outcomes [4].

Among various approaches for institutional analysis, the IAD framework is widely used because it is generalized and compatible with a wide range of analytical techniques, while still providing a common basis for integrating diverse policy elements [4].

Figure 2 shows the framework of the IAD approach. Following the analytical step, the first and the most important step is to identify the action arena, which is described as a conceptual space where the key interactions occur [4]. The action arena consists of (1) the participant, referring to individuals or groups of corporations; and (2) the action situation, referring to the social space where actors interact $[4,13]$. Although the terms "actor" and "participant" are interchangeable, the term "actor" is preferred in this work. Moreover, the IAD approach also identifies important elements or variable influencing actors which are (1) resources that an actor brings to a situation; (2) valuations or preferences which refer to the wishes of actors; (3) information processing which is the way actors 
acquire, process, retain, and use knowledge and information; and (4) selection processes which actors use to select a particular course of action. Consequently, to identify the action arena effectively, it is also important to analyze and understand the decision-making capabilities for policy work of actors.

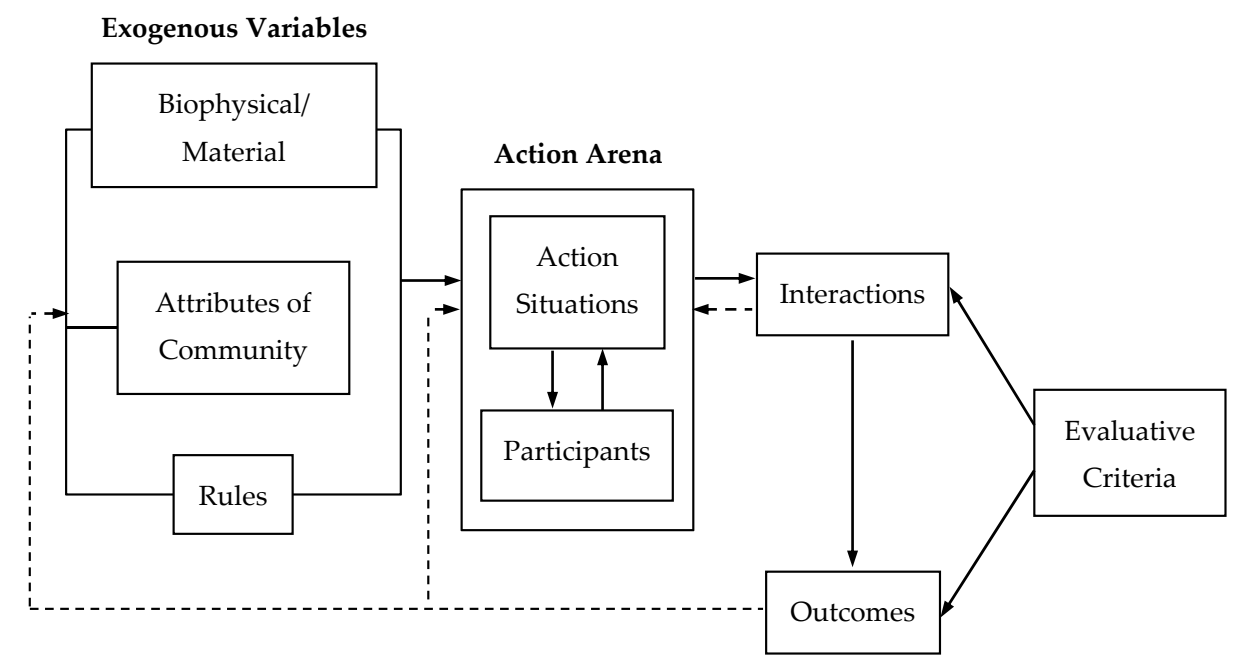

Figure 2. Institutional analytical and development (IAD) framework by Ostrom [13].

To understand the decisions of actors at different steps in the policy process, the concept of policy capacity, understood as the conditions of an organization to develop and implement policy effectively [3], was applied to the IAD framework for the benefit of examining the three government organizations (MoEN, MoNRE, and MoI) that are considered as actors involved in EFW development under AEDP 2015.

\subsection{Conceptualization of Policy Capacity}

The development of EFW as an important energy resource of Thailand requires the relevant government organizations to effectively conduct policy works, described as research and analysis, designing and recommending, clarifying arguments and values, and providing strategic advice and mediation [14]. Therefore, it is crucial to understand policy capacity, and the conditions for effective policy development and implementation [15]. Moreover, policy capacity is considered a precondition for policy success and superior policy outcomes [16,17].

Policy capacity is broadly used for policy assessment, especially for the government [18]; however, its definition and analytical concepts are still unclear and under discussion [19]. Numerous scholars, including Honadle [20], define policy capacity as "the ability to anticipate and influence change, make informed intelligent decisions about policy, develop programs to implement policy, attract and absorb resources, manage resources, and evaluate current activities to guide future actions". For Cummings and Nørgaard [21], policy capacity refers to "the intellectual and organizational resources of the state", while Painter and Pierre [22] define policy capacity as "the ability to marshal the necessary resources to make intelligent collective choices and set strategic directions for the allocation of scarce resource to public ends". Howlett [23] considers policy capacity as "the ability to frame options, the application of both qualitative and quantitative research methods to policy problems, and the effective use of communications, and stakeholder management strategies".

In addition to the unclear concept and definition of policy capacity, the identification of its components constitutes policy capacity. How skills and resources can be combined in policy capacity is also required because they result in the limited use of policy capacity [19]. To overcome the limitation of the policy capacity definition, Wu et al. [10] proposed an analytical framework for policy capacity by defining policy capacity as the set of skills and resources (or competences and capabilities) necessary to perform policy function. The framework is presented in the form of a $3 \times 3$ matrix model which 
consists of three skills or competences (analytical, operational, and political) at three different levels of resources or capabilities (individual, organizational, and systemic). As a result, nine components of policy capacity were generated. Moreover, some specific indicators of the policy capacity components were also suggested.

\section{Methodology}

\subsection{Literature Review}

To collect the required information that is relevant to governmental support for EFW development, policy process, and policy capacity, this research divided the context of the study into two parts: (1) context of Thai government organization in developing and supporting EFW, and (2) context involving the policy capacity and its application. To understand the roles and responsibilities of Thai government organizations in development and supporting EFW, relevant policies, action plans, official reports, and acts were reviewed, as shown in Table 1. Research articles related to policy capacity, analytical framework for policy capacity, and applications of policy capacity analysis, especially policy capacity at the organizational and systemic levels in different organizations and policy fields were also reviewed, as shown in Table 2.

Table 1. Sources of information related to energy-from-waste (EFW) support and development by the Thai government. AEDP—Alternative Energy Development Plan; MoEN-Ministry of Energy; MoNRE-Ministry of Natural Resources and Environment; MoI-Ministry of Interior.

\begin{tabular}{cc}
\hline Organizations & Documents \\
\hline \multirow{2}{*}{ MoEN } & AEDP 2015 \\
& AEDP 2015 Action Plan \\
MoNRE & Renewable and alternative energy annual reports \\
\hline \multirow{2}{*}{ MoI } & The National Solid Waste Management Master Plan (2016-2021) \\
Waste management annual reports
\end{tabular}

Table 2. The studied literatures related to policy capacity.

\begin{tabular}{cccc}
\hline Context & Year & Authors & References \\
\hline \multirow{2}{*}{ Analytical framework } & 2015 & Wu, Ramesh, and Howlett & {$[10]$} \\
& 2018 & Wu, Howlett, and Ramesh & {$[18]$} \\
\hline & 2015 & Dunlop & {$[24]$} \\
& 2009 & Gleeson et al. & {$[15]$} \\
Policy capacity at & 2011 & Gleeson et al. & {$[3]$} \\
organizational level & 2015 & Hughes & {$[19]$} \\
& 2015 & Pattyn and Brans & {$[25]$} \\
& 2015 & Peters & {$[26]$} \\
& 2016 & Ramesh, Howlett, and Wu & {$[27]$} \\
& 2015 & Wu, Ramesh, and Howlett & {$[10]$} \\
Policy capacity at & 2018 & Wu, Howlett, and Ramesh & {$[18]$} \\
\hline systemic level & 2015 & Hsu & {$[28]$} \\
& 2015 & Hughes & {$[19]$} \\
& 2016 & Ramesh, Howlett, and Wu & {$[27]$} \\
& 2015 & Woo et al. & {$[17]$} \\
& 2015 & Wu, Ramesh, and Howlett & {$[10]$} \\
& 2018 & Wu, Howlett, and Ramesh & {$[18]$} \\
\hline
\end{tabular}




\subsection{Expert Interviews}

An in-depth qualitative analysis was conducted through interviews with nine interviewees from three ministries in September 2017. Following the basic concept of interpretative phenomenological analysis [29], this research focused on the richness and the significance of information from interviewees rather than the number of interviewees. As a result, we carefully selected the interviewees based on their roles and responsibilities, contribution in policy processes, working experiences, and expertise.

The interviewees from the MoEN were selected because they were involved in AEDP 2015 since it was in the agenda-setting step and until it was approved as a master plan. The interviewees are involved in analyzing information and situations, and coordinating both internal and external organizations for identifying the policy problems, setting up policy assumptions and scenarios, and evaluating the alternative choices.

Similarly, the interviewees from the MoNRE were involved in setting up the National Solid Waste Master Plan form the beginning until it was approved. Moreover, they also worked with MoI officers to set up action plans for effective MSW management.

The interviewees from the MoI were selected because they worked in a city municipality to manage and improve the SWM system. Moreover, they also worked closely with local people through various policy activities.

Due to the different roles and responsibilities of the ministries involved in EFW development, the scope of the questions for each ministry was different. For MoEN interviewees, the questions focused on the policy process and cooperation, especially when AEDP 2015 was in the agenda-setting and policy formulation step. They were asked about the problems and difficulties faced during the process and the solutions, the requirements or support necessary for policy works, and how the policy could be improved. Interviewees from the MoNRE were asked questions focusing on their cooperation with the MoEN and MoI, policies and plans to support AEDP 2015, and the problems faced for the cooperation of all actors. Finally, interviewees from the MoI were mainly asked about their opinions about AEDP 2015, actions to support AEDP 2015, the waste management system (WMS) related to EFW, problems during work, and the required support. Numbers of interviewees and their contributions to policy work are shown in Table 3.

Table 3. Organizations, number of informants, and their contribution in policy process.

\begin{tabular}{ccc}
\hline Organizations & Number of Interviewees & Contributions in AEDP 2015 and/or EFW \\
\hline MoEN & 5 & Setting agendas, formulating, and making decisions for AEDP 2015 \\
MoNRE & 2 & $\begin{array}{c}\text { Setting agendas, formulating, and regulating the National Solid Waste } \\
\text { Management Master Plan } \\
\text { Approving funding for local administrative organizations }\end{array}$ \\
\hline MoI & 2 & Operating the waste management system \\
\hline
\end{tabular}

\section{Results}

This section presents factors contributing to policy capacity at the organizational and systemic level derived from the literature review. These factors were then arranged in accordance with the policy capacity components under the analytical framework for policy capacity developed by Wu et al. [18]. Then, the key findings were identified, and modification of the analytical framework was proposed. Finally, the modified analytical framework was used to analyze the policy capacity of Thai government organizations involved in EFW development under AEDP 2015 followed by the discussion of the results from the in-depth interviews.

\subsection{Factors Contributing to Policy Capacity}

Policy works are mainly accomplished by government organizations who play an important role in policy process [26]. To conduct policy process effectively, an organization has to support policy works at the individual level; therefore, its tasks are (1) to acquire and process information necessary for 
individual policy works; (2) to collect and disseminate information among organizations; (3) to mobilize and deploy the resources necessary for performing policy works; (4) to communicate and cooperate with relevant organizations; and (5) to evaluate the policy [18]. Consequently, an organization should realize its policy capacity to benefit from policy work development [13].

To understand policy capacity, it is important for an organization to know the factors contributing to its own policy capacity. Although Wu et al. [18] identified some factors and indicators that could be used as guidelines to analyze policy capacity in the analytical framework, these factors are not well organized and could not cover every element of the policy process. For example, (1) legitimacy for policy process; (2) process for stakeholder engagement; and (3) access to key policy maker are identified as the factors of organizational political capacity, which refers to the abilities of an organization to acquire support for its policy work. Although, these factors are important, other important factors such as skills in communication and persuasion are not included. Moreover, the factor "process for stakeholder engagement" cannot be confidently identified as a skill or resource.

As suggested by Howlett, Wellstead, and Craft [30], other factors that contribute to policy work should be considered in order to gain a better understanding of policy capacity's impact on policy process. To improve the analytical framework in accordance with the main tasks of an organization under the policy process, this article reviewed several articles studying policy capacity from different aspects to extend the variety of policy capacity factors at the organizational and systemic level, and they are summarized below.

Adequate and timely information and evidence are the most important resources for individuals to perform policy work effectively; moreover, it is considered as an indicator for policy capacity evaluation $[3,15]$. Therefore, it is the responsibility of an organization to acquire and process the required information and evidence for policy work at the individual level, which Wu et al. [18] considered to be organizational analytical capacity. To exercise organizational abilities in analysis, an organization requires resources, including adequately skilled staff, time, and tools for analysis and evaluation $[10,15,31]$. Furthermore, a systemic analytical capacity, described by Wu et al. [18] as an information system that supports an organization to manage information systematically, is required. With an effective and transparent information system, an organization can collect, process, evaluate, and disseminate the information necessary for policy work within and across the organization effectively [28]. Moreover, an organization can create the channels for stakeholders to participate in the information system for benefits in system development [28].

In addition to abilities of acquiring and processing information and evidence, an organization is also required to have the ability to manage the required resources necessary for effective policy implementation. Consequently, an organization requires leadership skills, described as performance in planning, staffing, budgeting, delegating, directing, coordinating, and managing the required resources and supporting the policy works $[15,18,19]$. In order to implement a policy effectively, Peters [26] identified information as an important resource, because an organization can use its information to negotiate for other required resources, while Hughes et al. [19] considered financial and human resources as the important resources. Although the important resources might differ, external and internal coordination processes for obtaining the required resources are similarly important for every organization [18]. In addition, organizations could implement their policy more effectively with support from a system that helps them manage cooperation and relationships. Wu et al. [18] called this operational capacity at the systemic level. This system can help an organization communicate with and control other relevant organizations; moreover, it also helps build and maintain relationships among stakeholders for the benefit of policy implementation. In addition to coherence and engagement of policy networks and communities, clarity in roles and responsibilities is an important factor that could also identify effective operation capacity at the systemic level [18].

To maintain the stability of a policy, an organization is required to gain and maintain support for its policy from different stakeholders. Wu et al. [18] defined these abilities as political capacity at the organizational level. Therefore, it is crucial for an organization to have skills in communicating and 
pursuing its own organization and policy goals [26]. Within the organization, policy goals, plans, and procedures are communicated; at the same time, the organization communicates and collaborates with other stakeholders [18]. Moreover, an organization should have an understanding of stakeholders to gain their policy support. Therefore, communication skills and a communication process that allows two-way communication between the organization and different stakeholders are required for a better understanding of each other [18]. Furthermore, trust is another factor to consider because it promotes public support for both policies and the organization [32,33]. Trust is not legal protection, but it is closely related to legitimacy, which Woo et al. [17] and Wu et al. [18] consider a factor necessary for political capacity. Similarly, Wu et al. [18] consider that a system that can enable stakeholder engagement and manage policy activities is necessary for an organization, and they define it as systemic political capacity. With an effective process for stakeholder engagement under the political system, an organization is able to maintain trust and increase the level for stakeholder participation and public support for its policy [18].

The three main skills and their broad definitions under the analytical framework developed by $\mathrm{Wu}$ et al. [10] are (1) analytical skills (the abilities required to make a technically sound policy), (2) operational skills (the abilities needed to guarantee that the policy is implementable), and (3) political skills (the abilities to support and sustain the policy).

Adopting these definitions, the factors contributing to policy capacity at the organizational and systemic level from the literature reviews were organized into the six policy capacity components, as shown in Table 4.

Table 4. Categorized factors contributing to policy capacity, following the analytical framework developed by Wu et al. [10].

\begin{tabular}{|c|c|c|c|}
\hline \multirow{2}{*}{ Level of Policy Capacity } & \multicolumn{3}{|c|}{ Factors Contributing to Policy Capacity } \\
\hline & Analytical Skills & Operational Skills & Political Skills \\
\hline Organizational Level & $\begin{array}{l}\text { - Information collection, } \\
\text { analysis, evaluation, } \\
\text { and dissemination } \\
\text { - Availability of adequately } \\
\text { skilled staff and time } \\
\text { - Tools for analysis } \\
\text { and evaluation }\end{array}$ & $\begin{array}{l}\text { - } \quad \text { Leadership and } \\
\text { management skills } \\
\text { - Availability of information, } \\
\text { human resources, and } \\
\text { financial resources } \\
\text { - } \quad \begin{array}{l}\text { External and internal } \\
\text { coordination process }\end{array}\end{array}$ & $\begin{array}{ll}\text { - } & \text { Skills in communication } \\
\text { and persuasion } \\
\text { - } & \text { Legitimacy of } \\
\text { - } & \text { policy process } \\
\text { - } & \text { Accessing process to } \\
\text { - } & \text { key policy-makers } \\
\text { Internal and external } \\
\text { communication process }\end{array}$ \\
\hline Systemic Level & $\begin{array}{l}\text { Information collection, } \\
\text { analysis, evaluation, } \\
\text { and dissemination } \\
\text { Effective and transparent } \\
\text { information system } \\
\text { - Channels for stakeholder } \\
\text { participation in } \\
\text { information system }\end{array}$ & 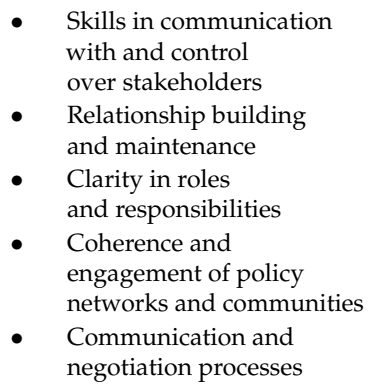 & $\begin{array}{ll}\text { - } & \text { Skills in enabling } \\
\text { stakeholder participation } \\
\text { and managing } \\
\text { policy activities } \\
\text { - } \quad \text { Level of stakeholder } \\
\text { participation, public } \\
\text { support, and trust } \\
\text { - } \\
\text { Stakeholder } \\
\text { participation process }\end{array}$ \\
\hline
\end{tabular}

\subsection{Key Findings and Recommendations for Analysing Policy Capacity}

Wu et al. $[10,18]$ constructed the analytical framework for policy capacity from the combination of skills (analytical, operation, and political) necessary for policy processes and the required resources at three different levels (individual, organizational, and systemic). Although we strongly agree that skills and resources are important elements of policy capacity, considering only skills and resources is not enough since these two elements are impacted by the processes used for developing policies [34]. Moreover, when considering the factors identified under the framework, processes for 
stakeholder engagement, data collection, and analysis are suggested as factors contributing to policy capacity, which could scarcely be considered as skills or resources. Furthermore, the importance of process in policy capacity is also supported by other research. For example, Tiernan and Wanna [35] defined capacity as "the structural and organizational resources and processes that contribute to the policy-making process", whereas Gleeson et al. [3] explained policy capacity as "the organizational structures, processes, and cultures that support effective policy development and implementation.

Therefore, we propose the processes that affect the decisions and actions necessary to conduct policy work as another important element of policy capacity. Consequently, skills, resources, and processes should be taken into consideration when policy capacity is analyzed or examined. Based on our findings (the incomprehensive consideration of policy capacity factors, effects of processes on skills and resources, and support for the importance of processes for policy capacity in other research), we propose to categorize the factors of policy capacity into three groups of elements: (1) skills; (2) resources; and (3) processes, since the factors suggested under the framework by Wu et al. [18] were not identified and categorized systematically.

Regarding the key elements of actors identified in the IAD approach, which are (1) resources; (2) preferences; (3) information processes; and (4) selection processes for courses of action [4], the categorization of policy capacity factors into skills, resources, and processes encourages the results to be used for analyzing policy capacity for further institutional analysis following the IAD approach.

Therefore, as shown in Table 5, the analytical framework for policy capacity should be improved by adding more relevant factors derived from Section 3.1 and by categorizing these factors into three groups of elements which are as follows:

(1) Skills-the abilities and expertise needed to conduct policy work effectively. Examples of these skills include analytical skills, coordination skills, and communication skills.

(2) Resources-any supplies and support that an organization brings to the policy process, such as information, human resources, coordination, trust, political support, and legitimacy.

(3) Processes that affect the decisions and actions required to conduct the policy work, for example, the communication process, internal and external coordination processes, and the stakeholder participation process.

Table 5. Three elements of policy capacity under the modified analytical framework at the organizational and systemic levels.

\begin{tabular}{|c|c|c|c|}
\hline \multirow{2}{*}{$\begin{array}{l}\text { Level of Resources } \\
\text { and Capabilities }\end{array}$} & \multicolumn{3}{|c|}{ Policy Capacity } \\
\hline & Analytical Skills & Operational Skills & Political Skills \\
\hline Organizational level & $\begin{array}{l}\text { - Skills: Information-acquiring } \\
\text { and processing skills } \\
\text { - } \quad \text { Resources: Adequately skilled } \\
\text { staff, time, and tools for } \\
\text { information analysis } \\
\text { and evaluation } \\
\text { - } \\
\text { Processes: Information } \\
\text { collection, analysis, } \\
\text { dissemination, and } \\
\text { evaluation processes }\end{array}$ & $\begin{array}{l}\text { - Skills: Leadership and } \\
\text { management skills } \\
\text { - Resources: Information, } \\
\text { human resources, and } \\
\text { financial resources } \\
\text { - Processes: External and } \\
\text { internal } \\
\text { coordination process }\end{array}$ & $\begin{array}{l}\text { - Skills: Communication and } \\
\text { persuasion skills } \\
\text { - } \quad \text { Resources: Legitimacy for } \\
\text { policy process, and } \\
\text { stakeholders' information } \\
\text { - } \quad \text { Processes: Accessible } \\
\text { processes to key } \\
\text { policy-makers, and internal } \\
\text { and external } \\
\text { communication processes }\end{array}$ \\
\hline Systemic level & $\begin{array}{l}\text { - Skills: Information collecting, } \\
\text { analyzing, evaluating, } \\
\text { and disseminating } \\
\text { Resources: Efficiency and } \\
\text { transparency of information } \\
\text { system, and channels for } \\
\text { stakeholder participation in } \\
\text { information system } \\
\text { - Processes: Information } \\
\text { collecting, processing, } \\
\text { evaluating, and disseminating }\end{array}$ & $\begin{array}{l}\text { - Skills: Communication and } \\
\text { control over stakeholders, } \\
\text { and building and } \\
\text { maintaining relationships } \\
\text { Resources: Coherence and } \\
\text { engagement of policy } \\
\text { networks and } \\
\text { communities, and clarity in } \\
\text { roles and responsibilities } \\
\text { Processes: Communication } \\
\text { and negotiation }\end{array}$ & 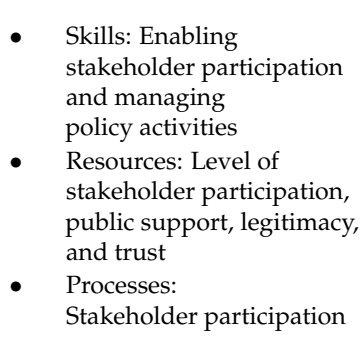 \\
\hline
\end{tabular}


It is believed that categorizing factors of policy capacity in this manner could create benefits by (1) improving the understanding of constituents of the policy process affecting policy capacity; (2) helping an organization scope out the area for policy capacity development; and (3) applying the policy capacity analysis to the IAD approach.

\subsection{Policy Capacity of the Thai Government}

The in-depth interview results are transcribed and summarized below. Then, the modified analytical framework was used to examine and analyze policy capacity at the organizational and systemic levels of the government organizations involved in EFW development under AEDP 2015.

\subsubsection{Ministry of Energy}

The MoEN is the main organization responsible for establishing energy plans, including AEDP 2015. Before starting the agenda-setting step, interviewees mentioned the internal coordination and communication required for ensuring all energy plans were consistent in the operational period. However, the deficiency of the required information emphasized the most serious problem faced during the agenda-setting and decision-making steps. The MoEN used various processes to acquire the required information, for example, sending formal letters asking for information from ministries, sending questionnaires to local organizations, and arranging formal meetings with relevant organizations. However, the information received was not enough to fulfil policy works effectively, especially the information about supplies and the forecasted supply of renewable energy resources. Moreover, the MoEN must apply different techniques and tools to analyze and evaluate the given information to forecast the missing information. Some interviewees also mentioned the inadequacy of human resources to conduct policy work and a lack of time due to the red tape of the Thai government system.

To develop cooperation, the MoEN tried communicating and cooperating with other government organizations by sharing ideas and setting up policy action plans in accordance with relevant policies from different ministries. However, interviewees mentioned there were difficulties in establishing policies that were truly harmonized among different ministries because it was difficult to coordinate among government organizations at the in-depth level.

To obtain policy support, the MoEN organized public hearings, expert discussions, and focus group meetings to gain feedback and suggestions from stakeholders before making final decisions for all energy plans. A high level of interest and participation from stakeholders was mentioned. However, it is challenging for the MoEN to balance stakeholder benefits and serving the government direction in national renewable energy at the same time. Therefore, the MoEN must analyze the feasibility of policy choices and propose alternatives that balance the benefits to all stakeholders, including the government who has full power in making the policy decision.

\subsubsection{Ministry of Natural Resources and Environment}

The MoNRE is responsible for establishing the National Solid Waste Master Plan that cascaded into short-term action plans that were implemented by the MoI. Interviewees mentioned that the MoNRE took advantage of a fire incident at the open dumpsite to push the waste management problem onto the national agenda. As a result, the government assigned the MoNRE and MoI to cooperate with each other to solve the problem.

To serve the government, the MoNRE advised the MoI in establishing the action plan "Thai Zero Waste" (2016-2017) and monitored the actions of the MoI in implementing the plan. Therefore, the MoNRE considered itself a regulator and consultant for the MoI in managing waste, especially for technical and information support. The MoNRE shared technical information, knowledge of waste management technologies, and feasibility studies with the MoI, while the MoI shared information about waste management results with the MoNRE. However, the MoI made the decisions in implementing the plan and operating the waste management system. An interviewee gave an example of the 
difference in the categorization of waste collection centers, for which the MoNRE considered the appropriateness of technology by consulting with the private sector, while the MoI categorized the centers based on the study report by the university.

Therefore, the main constraint for the MoNRE mentioned by the interviewees was the clarity of roles and responsibilities, especially as a regulator, because the MoI conducts policy work based on its judgment and decisions. Consequently, the MoNRE who monitors the actions of the MoI cannot regulate or force the MoI to take actions for policy success. The inadequacy of human resources was mentioned, as it impacts the monitoring process and collecting of information. Moreover, financial resources are another concern because the government did not approve $100 \%$ of the proposed budget for waste management investment; therefore, the MoNRE must encourage the private sector to invest in the remainder to achieve the policy target.

\subsubsection{Ministry of Interior}

The MoI works closely with local authorities and local people due to its responsibilities in operating waste management. Coordinating with the MoNRE, the MoI agreed and responded to the Thai Zero Waste action plan to support the National Solid Waste Master Plan. The MoI supported the MoNRE in promoting waste separation, and in applying the 3Rs through direct communication and arrangement of activities with local people. However, interviewees mentioned that campaigns or projects involving changing the behavior of local people should be conducted continuously for certainty of achieving maximum results. Previously, these projects were stopped or ended once the target was reached.

Considering waste treatment and management, an interviewee reported the difficulty in conducting operational works due to the lack of human resources. However, interviewees showed the confidence in the knowledge and expertise of their staff in waste management, which could impact the way they consult with the MoNRE.

The inadequacy of human resources does not only impact routine waste management practices, but also the collection and dissemination of information about waste management, which is required by many sectors. Interviewees mentioned the effort in collecting the information, but noted it was not their main responsibility. Moreover, a system that collects information in the standard format is required as it helps reduce burdens in filling the required information in different formats and reducing duplicate information sharing.

The categorized factors for policy capacity at the organizational and systemic level were used to examine the policy capacity of the Thai government involving EFW development. The statuses of policy capacity of each ministry (based on the interview results) were summarized and are shown in Table 6.

Based on the analysis of policy capacity of Thai government organizations involved in EFW development, the importance of each policy capacity component depends on the steps under the policy process that an organization is involved in. Therefore, to answer the theoretical question asked in $\mathrm{Wu}$ et al.'s [11] research about the weighting that should be attributed to the capacity if one capacity is more important than others, this article considered the impact to capacity of involving a different step in the policy process.

Based on the interview results, the analytical capacity is the most important capacity for the MoEN since it directly affects agenda setting and policy formulation for AEDP 2015, which is considered a long-term policy. The MoEN shows ability in acquiring and processing the required information, but some information does not exist due to the inefficient information processes, especially information collection and dissemination. 
Table 6. The examined policy capacity of government organizations as noted from in-depth interviews.

\begin{tabular}{|c|c|c|c|c|}
\hline \multirow{2}{*}{ Policy Capacity Component } & \multirow{2}{*}{$\begin{array}{l}\text { Categorized Factors Contributing to } \\
\text { Policy Capacity }\end{array}$} & \multicolumn{3}{|c|}{ Government Organizations } \\
\hline & & MoEN & MoNRE & MoI \\
\hline \multirow{3}{*}{$\begin{array}{c}\text { Organizational Analytical } \\
\text { Capacity }\end{array}$} & $\begin{array}{l}\text { Skills: Information acquiring and } \\
\text { processing }\end{array}$ & $\begin{array}{l}\text { Abilities in acquiring and processing } \\
\text { the required information for policy } \\
\text { were demonstrated. }\end{array}$ & $\begin{array}{l}\text { The MoNRE can acquire and process } \\
\text { the required information necessary } \\
\text { for policy works. }\end{array}$ & Not mentioned. \\
\hline & $\begin{array}{l}\text { Resources: Adequately skilled staff, } \\
\text { time, and tools for information } \\
\text { analysis and evaluation }\end{array}$ & $\begin{array}{l}\text { Even though the MoEN applies various } \\
\text { tools for helping analyze and evaluate } \\
\text { the acquired information, more human } \\
\text { resources are still required due to the } \\
\text { quality of the information. }\end{array}$ & $\begin{array}{l}\text { The MoNRE uses different analytical } \\
\text { information and evaluation needed to } \\
\text { overcome the limitation of human } \\
\text { resources. }\end{array}$ & Not mentioned. \\
\hline & $\begin{array}{l}\text { Processes: Information acquisition, } \\
\text { analysis, dissemination, and } \\
\text { evaluation }\end{array}$ & $\begin{array}{l}\text { Different processes and methods were } \\
\text { used to acquire and process the } \\
\text { required information, such as sending } \\
\text { formal letters and questionnaires, } \\
\text { discussing with relevant organizations, } \\
\text { cross-checking the received } \\
\text { information, and forecasting the } \\
\text { missing information. }\end{array}$ & $\begin{array}{l}\text { The inspection manual was used by } \\
\text { local organizations to evaluate the } \\
\text { situations and information for the } \\
\text { MoNRE. Moreover, sending formal } \\
\text { letters, discussing with the relevant } \\
\text { organizations, and searching for the } \\
\text { required information from secondary } \\
\text { data were also used. }\end{array}$ & $\begin{array}{l}\text { The MoI disseminated the existing } \\
\text { information when there was a request } \\
\text { from other organizations. }\end{array}$ \\
\hline \multirow{3}{*}{$\begin{array}{l}\text { Organizational Operational } \\
\text { Capacity }\end{array}$} & Skills: Leadership and management & $\begin{array}{l}\text { The MoEN prepared counterplans for } \\
\text { the flexibility in conducting future } \\
\text { activities and projects if the approved } \\
\text { budget was lower than the expectation. }\end{array}$ & $\begin{array}{l}\text { The MoNRE plans to solve the } \\
\text { inadequate budget by encouraging } \\
\text { coordination from private sectors. }\end{array}$ & $\begin{array}{l}\text { The MoI manages and directs its } \\
\text { policy activities and projects through } \\
\text { the cooperation of local delegates } \\
\text { such as community leaders, teachers, } \\
\text { and monks. }\end{array}$ \\
\hline & $\begin{array}{l}\text { Resources: Information, human } \\
\text { resources, and financial resources }\end{array}$ & $\begin{array}{l}\text { The MoEN required more staff to deal } \\
\text { with various information sources } \\
\text { related to policy works. Moreover, the } \\
\text { expected budgets for AEDP } 2015 \text { might } \\
\text { be adjusted by government. }\end{array}$ & $\begin{array}{l}\text { The MoNRE faced the challenge of } \\
\text { inadequacy of timely and updated } \\
\text { information, human resources, and } \\
\text { the approved budget. }\end{array}$ & $\begin{array}{l}\text { The MoI requires information, human } \\
\text { resources, and financial resources to } \\
\text { establish and operate } 18 \text { waste } \\
\text { collection centers effectively; } \\
\text { however, the expected annual budget } \\
\text { might be changed by the government. }\end{array}$ \\
\hline & $\begin{array}{l}\text { Processes: External and internal } \\
\text { coordination }\end{array}$ & $\begin{array}{l}\text { Internally, the MoEN set all energy } \\
\text { plans consistently to support each other. } \\
\text { Externally, the MoEN tried sharing } \\
\text { information, communicating, and } \\
\text { consulting with other organizations to } \\
\text { adjust the energy plans in harmony } \\
\text { with other relevant policies. }\end{array}$ & $\begin{array}{l}\text { The MoNRE consulted and } \\
\text { coordinated internally to adjust the } \\
\text { regulations for renewable energy } \\
\text { plan approval. Externally, the } \\
\text { MoNRE consulted and shared } \\
\text { information with the MoI to establish } \\
\text { the action plans to support the } \\
\text { National Solid Waste Master Plan. }\end{array}$ & $\begin{array}{l}\text { The MoI communicated and } \\
\text { cooperated internally to conduct } \\
\text { policy works among teams. } \\
\text { Externally, the MoI worked with the } \\
\text { MoNRE to establish action plans to } \\
\text { support the waste management } \\
\text { roadmap, and shared its information } \\
\text { with relevant organizations. }\end{array}$ \\
\hline
\end{tabular}


Table 6. Cont

\begin{tabular}{|c|c|c|c|c|}
\hline \multirow{3}{*}{$\begin{array}{c}\text { Organizational Political } \\
\text { Capacity }\end{array}$} & $\begin{array}{l}\text { Skills: Communication and } \\
\text { persuasion }\end{array}$ & $\begin{array}{l}\text { The MoEN communicated within and } \\
\text { outside organizations to gain support } \\
\text { for policy works with different groups } \\
\text { of stakeholders. }\end{array}$ & $\begin{array}{l}\text { The MoNRE communicated with } \\
\text { other organizations to share } \\
\text { information and gain support for its } \\
\text { policy works. }\end{array}$ & $\begin{array}{l}\text { The MoI mainly communicated and } \\
\text { persuaded local authorities to } \\
\text { participate and support its policy } \\
\text { works. }\end{array}$ \\
\hline & $\begin{array}{l}\text { Resources: Legitimacy for policy } \\
\text { process, and stakeholders' } \\
\text { information }\end{array}$ & $\begin{array}{l}\text { The MoEN used the information of } \\
\text { different groups of stakeholders to } \\
\text { establish and implement energy } \\
\text { policies consistent with the direction } \\
\text { and final decision made by the } \\
\text { government. }\end{array}$ & $\begin{array}{l}\text { The MoNRE was assigned by the } \\
\text { government to solve the waste } \\
\text { management problem urgently by } \\
\text { setting up the waste management } \\
\text { roadmap. }\end{array}$ & $\begin{array}{l}\text { The MoI was assigned by the } \\
\text { government to establish the waste } \\
\text { management action plans and work } \\
\text { corporately with the MoNRE to solve } \\
\text { waste management problems. }\end{array}$ \\
\hline & $\begin{array}{l}\text { Processes: Access to key } \\
\text { policy-makers, and internal and } \\
\text { external communication }\end{array}$ & $\begin{array}{l}\text { The MoEN accessed key policy-makers } \\
\text { through formal proposals and reports. } \\
\text { Moreover, the MoEN analyzed and } \\
\text { consulted within organizations to select } \\
\text { some special groups of stakeholders, } \\
\text { such as energy experts. }\end{array}$ & $\begin{array}{l}\text { The MoNRE accessed key } \\
\text { policy-makers by raising the waste } \\
\text { management problem and causing it } \\
\text { to be on the national agenda. }\end{array}$ & $\begin{array}{l}\text { The MoI consulted and } \\
\text { communicated with the MoNRE for } \\
\text { support of the waste management } \\
\text { action plans. }\end{array}$ \\
\hline \multirow{3}{*}{ Systemic Analytical Capacity } & $\begin{array}{l}\text { Skills: Information collecting, } \\
\text { analyzing, evaluating, and } \\
\text { disseminating }\end{array}$ & $\begin{array}{l}\text { The MoEN tried collecting the received } \\
\text { information, and analyzed, evaluated, } \\
\text { and disseminated it -systematically } \\
\text { within the organization. }\end{array}$ & $\begin{array}{l}\text { The MoNRE tried analyzing and } \\
\text { evaluating the received information } \\
\text { systematically. }\end{array}$ & $\begin{array}{l}\text { The MoI lacks the skills in collecting } \\
\text { and disseminating information } \\
\text { systemically. }\end{array}$ \\
\hline & $\begin{array}{l}\text { Resources: Efficiency and } \\
\text { transparency of information system } \\
\text { including channels for stakeholder } \\
\text { participation }\end{array}$ & $\begin{array}{l}\text { The MoEN lacks an effective and } \\
\text { transparent information system and } \\
\text { formal channels for stakeholder } \\
\text { participation in the information system. }\end{array}$ & $\begin{array}{l}\text { The MoNRE lacks an effective and } \\
\text { transparent information system and } \\
\text { formal channels for stakeholder } \\
\text { participation in the information } \\
\text { system. }\end{array}$ & $\begin{array}{l}\text { The MoI lacks an effective and } \\
\text { transparent information system and } \\
\text { formal channels for stakeholder } \\
\text { participation in the information } \\
\text { system. }\end{array}$ \\
\hline & $\begin{array}{l}\text { Processes: Information collecting, } \\
\text { processing, evaluating, and } \\
\text { disseminating }\end{array}$ & $\begin{array}{l}\text { The MoEN used different techniques to } \\
\text { process and evaluate the received } \\
\text { information, then collected and } \\
\text { disseminated the information within } \\
\text { the organization through internal } \\
\text { reports and discussions. }\end{array}$ & $\begin{array}{l}\text { The MoNRE used different } \\
\text { techniques to process and evaluate } \\
\text { the received information and } \\
\text { disseminate the information through } \\
\text { annual reports, meetings, and } \\
\text { discussions. }\end{array}$ & $\begin{array}{l}\text { The MoI requires a standard format } \\
\text { for information collection and central } \\
\text { channels to disseminate accurate and } \\
\text { timely information to the relevant } \\
\text { organizations. }\end{array}$ \\
\hline
\end{tabular}


Table 6. Cont.

\begin{tabular}{|c|c|c|c|c|}
\hline \multirow{3}{*}{ Systemic Operational Capacity } & $\begin{array}{l}\text { Skills: Communication and control } \\
\text { over stakeholders, and building and } \\
\text { maintaining relationships }\end{array}$ & $\begin{array}{l}\text { The MoEN communicated with other } \\
\text { organizations and stakeholders to build } \\
\text { and maintain support for policy works. }\end{array}$ & $\begin{array}{l}\text { The MoNRE communicated with } \\
\text { other organizations to maintain their } \\
\text { relationships and to monitor policy } \\
\text { implementation. }\end{array}$ & $\begin{array}{l}\text { The MoI communicated and } \\
\text { controlled the local authorities to } \\
\text { build and maintain their relationships } \\
\text { for the support of policy works. }\end{array}$ \\
\hline & $\begin{array}{l}\text { Resources: Coherence and } \\
\text { engagement of policy networks and } \\
\text { communities, and clarity in roles and } \\
\text { responsibilities }\end{array}$ & $\begin{array}{l}\text { The MoEN tried working coherently, } \\
\text { especially with private sectors and local } \\
\text { communities. }\end{array}$ & $\begin{array}{l}\text { The MoNRE requires clarity in roles } \\
\text { and responsibility, especially as a } \\
\text { regulator of the MoI. }\end{array}$ & $\begin{array}{l}\text { The MoI works closely with local } \\
\text { authorities and communities. }\end{array}$ \\
\hline & $\begin{array}{l}\text { Processes: Communication and } \\
\text { negotiation }\end{array}$ & $\begin{array}{l}\text { The MoEN communicated and } \\
\text { negotiated with stakeholders through } \\
\text { the public hearing process to balance } \\
\text { the interests and benefits of all } \\
\text { stakeholders. }\end{array}$ & $\begin{array}{l}\text { The MoNRE communicated with } \\
\text { stakeholders through the public } \\
\text { hearing process and negotiated with } \\
\text { relevant organizations through } \\
\text { discussions and consultations. }\end{array}$ & $\begin{array}{l}\text { The MoI communicated and } \\
\text { negotiated with stakeholders, } \\
\text { especially local authorities, through } \\
\text { public hearings and different policy } \\
\text { activities. }\end{array}$ \\
\hline \multirow{3}{*}{ Systemic Political Capacity } & $\begin{array}{l}\text { Skills: Enabling stakeholder } \\
\text { participation, and skills in managing } \\
\text { policy activities }\end{array}$ & $\begin{array}{l}\text { The MoEN showed effective abilities in } \\
\text { enabling stakeholder participation by } \\
\text { arranging various policy activities to } \\
\text { gain support from different sectors of } \\
\text { stakeholders. }\end{array}$ & $\begin{array}{l}\text { The MoNRE enabled stakeholder } \\
\text { participation and managed different } \\
\text { policy activities. }\end{array}$ & $\begin{array}{l}\text { The MoI received good participation } \\
\text { in different policy projects and } \\
\text { activities from local authorities, } \\
\text { communities, and private sectors. }\end{array}$ \\
\hline & $\begin{array}{l}\text { Resources: Level of stakeholder } \\
\text { participation, public support, } \\
\text { legitimacy, and trust. }\end{array}$ & $\begin{array}{l}\text { AEDP } 2015 \text { was supported by various } \\
\text { sectors which reflected a high level of } \\
\text { stakeholder participation and interest } \\
\text { during the policy process, especially } \\
\text { public hearings. However, stability and } \\
\text { continuity of the policy and incentive } \\
\text { measures were questioned by the } \\
\text { private sector. }\end{array}$ & $\begin{array}{l}\text { Level of stakeholder participation } \\
\text { was not mentioned. However, the } \\
\text { MoI supports the MoNRE and works } \\
\text { with locals concerned about the } \\
\text { continuity of policy projects and } \\
\text { activities launched by the MoNRE. }\end{array}$ & $\begin{array}{l}\text { High level of stakeholder } \\
\text { participation and public support was } \\
\text { reflected in different policy activities } \\
\text { and projects. However, the } \\
\text { discontinuity of past projects and } \\
\text { activities might affect the level of } \\
\text { participation in future. }\end{array}$ \\
\hline & Processes: Stakeholder participation & $\begin{array}{l}\text { Public hearings, focused group } \\
\text { meetings, and expert discussions were } \\
\text { the processes used by the MoEN to } \\
\text { encourage stakeholder participation. }\end{array}$ & $\begin{array}{l}\text { The MoNRE uses public hearing } \\
\text { processes for stakeholder } \\
\text { participation. }\end{array}$ & $\begin{array}{l}\text { Similar to the MoEN and the MoNRE } \\
\text { the MoI also uses public hearings as } \\
\text { the main process for stakeholder } \\
\text { participation. }\end{array}$ \\
\hline
\end{tabular}


For the MoNRE interviewees, systemic operational capacity is the most important capacity based on the interview results. Although the MoNRE supports EFW development through its involvement in SWM, which is considered a policy implementation step, it is indirectly involved because they regulate the MoI, who operates and manages the waste management system directly. Therefore, the MoNRE focuses more on the capacity that supports their operational capacity which is considered a systemic operational capacity.

Although the interviewees from the MoEN and MoNRE mentioned the impact of the MoI's analytical capacity, especially the process for information collection and dissemination, for the MoI interviewees, the operational capacity is the most important. Considering the involvement in policy process, the MoI mainly uses the policy implementation step as the operator for the SWM system. Consequently, the main concern of MoI interviewees was the operation capacity, especially human resources, which they consider to be an important factor necessary for conducting their work.

Cooperation among relevant government organizations is important to conduct policy works effectively. Therefore, it is important to understand the policy capacity of different organizations because it affects the whole policy process. Moreover, as shown by the results, an organization also values its own capacity and others' capacity differently. Therefore, categorizing factors of policy capacity into skills, resources, and processes facilitates an organization to understand its policy capacity and policy capacity impacts, and to identify the missing or inefficient policy capacity factors systematically. Consequently, it benefits Thai government organizations to improve their cooperation under the policy process to achieve the EFW development target under AEDP 2015.

\section{Discussion and Conclusions}

This article studied the challenges of the Thai EFW development plan from the perspective of institutional analysis by examining policy capacity, described as the conditions for effective policy development and implementation that affect the decision-making and interaction of the relevant government organizations.

We studied the policy capacity of Thai government organizations involved in EFW development under AEDP 2015 at the organizational and systemic level. The information was acquired through a literature review and in-depth interviews which carefully selected interviewees. The results of this research are based on the judgment of the interviewees that reflect the factors contributing to policy capacity.

According to the reviewed literature, policy capacity is mainly applied in the health sector and public organizations, which benefits the development of policy and policy implementation $[3,15,19,24]$. Therefore, we believe that applying the policy capacity analysis to the Thai energy sector can broaden our understanding of the challenges of EFW development from a different perspective.

We started with the analytical framework for policy capacity developed by Wu et al. [10], and modified it by adding more factors that contribute to policy capacity, as derived from the literature review, and adopted the key elements of actor identification under the IAD approach to link policy capacity analysis to the IAD framework.

We found that factors contributing to policy capacity could be categorized in a more systematic manner. Following the combination of policy capacity and elements of actors from the IAD approach, this article contributes to improving the existing analytical framework for policy capacity by categorizing factors of policy capacity into three groups: (1) skills, described by the abilities and expertise of an organization in conducting policy work effectively; (2) resources, described as the supply or support that an organization brings into the policy process; and (3) processes that affect the decisions and actions necessary to conduct policy works. Moreover, the modified analytical framework is compatible with the IAD approach which could facilitate the utilization of policy capacity analysis results for further analysis under the IAD framework.

For the Thai government organizations involved in EFW development, the modified analytical framework encourages the understanding of current policy capacity and its impact on other 
organizations, since an organization values its own policy capacity and others' policy capacity differently. Moreover, categorizing policy factors into skills, resources, and processes facilitates an organization to understand its policy capacity, and to identify the missing or inefficient policy capacity factors systematically. As a result, we believe that this understanding promotes the improvement of cooperation among Thai government organizations involved in EFW development.

For further development of policy capacity understanding, future research is recommended to study the relationships among factors of policy capacity affecting individual steps of the policy process. Moreover, a study regarding the impact of policy capacity on the interactions of relevant organizations for a particular policy is needed.

Author Contributions: Conceptualization, H.C. Data collection and interview, H.C. Data and result analysis, H.C. and T.W. Supervision, T.W. Writing—original draft, H.C. Writing—review and editing, H.C. and T.W.

Funding: This research received no external funding.

Conflicts of Interest: The authors declare no conflicts of interest.

\section{Acronyms}

$3 R s$

AEDP 2015

EEDP

EFW

IAD

MoEN

MoI

MoNRE

PDP

SWM

TIEB

WTE
Reduce, Reuse, and Recycle

Alternative Energy Development Plan 2015

Energy Efficiency Development Plan

Energy from waste

Institutional analytical and development

Ministry of Energy

Ministry of Interior

Ministry of Natural Resources and Environment

Power Development Plan

Solid Waste Management

Thailand Integrated Energy Blueprint

Waste to energy

\section{References}

1. Energy Policy and Planning Office (EPPO). Thailand Integrated Energy Blueprint (TIEB). Available online: http: / / www.eppo.go.th/index.php/en/policy-and-plan/en-tieb/tieb-pdp\#\&Itemid=813 (accessed on 24 July 2018).

2. Department of Alternative Energy Development and Efficiency (DEDE). Alternative Energy Development Plan: AEDP2015; Department of Alternative Energy Development and Efficiency (DEDE): Bangkok, Thailand, 2015.

3. Gleeson, D.; Legge, D.; O'Neill, D.; Pfeffer, M. Negotiating Tensions in Developing Organizational Policy Capacity: Comparative Lessons to be Drawn. J. Comp. Policy Anal. Res. Pract. 2011, 13, 237-263. [CrossRef]

4. Polski, M.M.; Ostrom, E. An Institutional Framework for Policy Analysis and Design. In Workshop in Political Theory and Policy Analysis Working Paper W98-27; Indiana University: Bloomington, Indiana, February 1999.

5. Srisaeng, N.; Tippayawong, N.; Tippayawong, K.Y. Energetic and Economic Feasibility of RDF to Energy Plant for a Local Thai Municipality. Energy Procedia 2017, 110, 115-120. [CrossRef]

6. Sukholthaman, P.; Sharp, A. A system dynamics model to evaluate effects of source separation of municipal solid waste management: A case of Bangkok, Thailand. Waste Manag. 2016, 52, 50-61. [CrossRef] [PubMed]

7. Vassanadumrongdee, S.; Kittipongvises, S. Factors influencing source separation intention and willingness to pay for improving waste management in Bangkok, Thailand. Sustain. Environ. Res. 2018, 28, 90-99. [CrossRef]

8. Makarichi, L.; Jutidamrongphan, W.; Techato, K. The evolution of waste-to-energy incineration: A review. Renew. Sustain. Energy Rev. 2018, 91, 812-821. [CrossRef]

9. Menikpura, S.N.M.; Sang-Arun, J.; Bengtsson, M. Assessment of environmental and economic performance of Waste-to-Energy facilities in Thai cities. Renew. Energy 2016, 86, 576-584. [CrossRef]

10. Wu, X.; Ramesh, M.; Howlett, M. Policy capacity: A conceptual framework for understanding policy competences and capabilities. Policy Soc. 2015, 34, 165-171. [CrossRef] 
11. Pollution Control Department (PCD). National Solid Waste Management Master Plan (2016-2021); Pollution Control Department (PCD): Bangkok, Thailand, 2016.

12. Office of the Council of State (OCS) Act on the Maintenance of the Cleanliness and Orderliness of the Country, B.E. 2560. Available online: http:/ /laws.anamai.moph.go.th/ewtadmin/ewt/laws/download/ about_laws_2017/laws_concerned/Announce_07.pdf (accessed on 25 July 2018).

13. Ostrom, E. Institutional Analysis and Development: Elements of the framework in historical perspective. Hist. Dev. Theor. Approaches Sociol. 2010, 2, 401.

14. Wellstead, A.M.; Stedman, R.C.; Lindquist, E.A. The Nature of Regional Policy Work in Canada's Federal Public Service. Can. Polit. Sci. Rev. 2009, 3, 34-56.

15. Gleeson, D.H.; Legge, D.G.; O'Neill, D. Evaluating health policy capacity: Learning from international and Australian experience. Aust. N. Z. Health Policy 2009, 6, 1-15. [CrossRef] [PubMed]

16. Howlett, M.; Ramesh, M. The two orders of governance failure: Design mismatches and policy capacity issues in modern governance. Policy Soc. 2014, 33, 317-327. [CrossRef]

17. Woo, J.J.; Ramesh, M.; Howlett, M. Legitimation capacity: System-level resources and political skills in public policy. Policy Soc. 2015, 34, 271-283. [CrossRef]

18. Wu, X.; Ramesh, M.; Howlett, M. Policy Capacity: Conceptual Framework and Essential Components. In Policy Capacity and Governance; Wu, X., Howlett, M., Ramesh, M., Eds.; Springer International Publishing: Cham, Germany, 2018; pp. 1-25. ISBN 978-3-319-54674-2.

19. Hughes, A.; Gleeson, D.; Legge, D.; Lin, V. Governance and policy capacity in health development and implementation in Australia. Policy Soc. 2015, 34, 229-245. [CrossRef]

20. Honadle, B.W. A capacity-building framework: A search for concept and purpose. Public Adm. Rev. 1981, 41, 575-580. [CrossRef]

21. Cummings, S.N.; Nørgaard, O. Conceptualising state capacity: Comparing Kazakhstan and Kyrgyzstan. Polit. Stud. 2004, 52, 685-708. [CrossRef]

22. Challenges to State Policy Capacity; Painter, M.; Pierre, J. (Eds.) Palgrave Macmillan UK: London, UK, 2005; ISBN 978-1-349-51825-8.

23. Howlett, M. Policy analytical capacity and evidence-based policy-making: Lessons from Canada. Can. Public Adm. 2009, 52, 153-175. [CrossRef]

24. Dunlop, C.A. Organizational political capacity as learning. Policy Soc. 2015, 34, 259-270. [CrossRef]

25. Pattyn, V.; Brans, M. Organisational analytical capacity: Policy evaluation in Belgium. Policy Soc. 2015, 34, 183-196. [CrossRef]

26. Peters, B.G. Policy capacity in public administration. Policy Soc. 2015, 34, 219-228. [CrossRef]

27. Ramesh, M.; Howlett, M.P.; Wu, X. Rethinking Governance Capacity as Organizational and Systemic Resources. SSRN Electron. J. 2016. [CrossRef]

28. Angel, H. Measuring policy analytical capacity for the environment: A case for engaging new actors. Policy Soc. 2015, 34, 197-208. [CrossRef]

29. Smith, J.A.; Osborn, M. Interpretative phenomenological analysis: Theory, method and research. In Interpretative Phenomenological Analysis; SAGE: Los Angeles, CA, USA, 2009; pp. 53-80.

30. Howlett, M.; Wellstead, A.; Craft, J. Policy Work in Canada: Professional Practices and Analytical Capacities in Canada's Policy Advisory System; Michigan Tech: Houghton, MI, USA, 2017.

31. Ramesh, M.; Howlett, M.P.; Saguin, K. Measuring Individual-Level Analytical, Managerial and Political Policy Capacity: A Survey Instrument. SSRN Electron. J. 2016. [CrossRef]

32. Rudolph, T.J. Political Trust, Ideology, and Public Support for Tax Cuts. Public Opin. Q. 2009, 73, $144-158$. [CrossRef]

33. Rudolph, T.J.; Evans, J. Political Trust, Ideology, and Public Support for Government Spending. Am. J. Pol. Sci. 2005, 49, 660-671. [CrossRef] 
34. Thissen, W.A.H.; Twaalfhoven, P.G.J. Towards a conceptual structure for evaluating policy analytic activities. Eur. J. Oper. Res. 2001, 129, 627-649. [CrossRef]

35. Tiernan, A.; Wanna, J. Competence, capacity, capability: Towards conceptual clarity in the discourse of declining policy skills. In Proceedings of the GovNet International Conference, Canberra, Australia, 28 November 2006.

(c)

(C) 2018 by the authors. Licensee MDPI, Basel, Switzerland. This article is an open access article distributed under the terms and conditions of the Creative Commons Attribution (CC BY) license (http:/ / creativecommons.org/licenses/by/4.0/). 